\title{
Entry Level Systems Analysts: What Does the Industry Want?
}

\author{
Erastus Karanja and Donna M. Grant \\ North Carolina Central University, Durham, NC, USA
}

ekaranja@nccu.edu; grantd@nccu.edu

\section{Shinetta Freeman \\ Goddard Space Flight Center, Bowie, MD, USA}

shinettafreeman@gmail.com

\author{
David Anyiwo \\ Bowie State University, Bowie, \\ MD, USA
}

\author{
danyiwo@bowiestate.edu
}

\begin{abstract}
This study investigates the skill sets necessary for entry level systems analysts. Towards this end, the study combines two sources of data, namely, a content analysis of 200 systems analysts' online job advertisements and a survey of 20 senior Information Systems (IS) professionals. Based on Chi-square tests, the results reveal that most employers prefer entry level systems analysts with an undergraduate Computer Science degree. Furthermore, most of the employers prefer entry level systems analysts to have some years of experience as well as industry certifications. The results also reveal that there is a higher preference for entry level systems analysts who have non-technical and people skills (e.g., problem solving and oral communication). The empirical results from this study will inform IS educators as they develop future systems analysts. Additionally, the results will be useful to the aspiring systems analysts who need to make sure that they have the necessary job skills before graduating and entering the labor market.
\end{abstract}

Keywords: System Analysts, Information Systems, Education, Skills, Content Analysis, Empirical Study

\section{Introduction}

The Information Systems major (we hereafter use IS to refer to Management Information Systems, Information Systems, Computer Information Systems, as well as the other variants of the IS related majors) is characterized by rapid growth and constant evolution. Likewise, systems ana-

Material published as part of this publication, either on-line or in print, is copyrighted by the Informing Science Institute. Permission to make digital or paper copy of part or all of these works for personal or classroom use is granted without fee provided that the copies are not made or distributed for profit or commercial advantage AND that copies 1) bear this notice in full and 2) give the full citation on the first page. It is permissible to abstract these works so long as credit is given. To copy in all other cases or to republish or to post on a server or to redistribute to lists requires specific permission and payment of a fee. Contact Publisher@InformingScience.org to request redistribution permission. lysts are required to have a range of skills and knowledge and to constantly update their skills and knowledge in order to remain competent (Joseph, Ang, Change, \& Slaughter, 2010). The skills and knowledge requirements for system analysts are encapsulated in the IS 2010 model curriculum (Topi et al., 2010), in which System Analysis \& Design (SA\&D) is described as the course that, 
“....discusses the processes, methods, techniques and tools that organizations use to determine how they should conduct their business, with a particular focus on how computer-based technologies can most effectively contribute to the way business is organized. The course covers a systematic methodology for analyzing a business problem or opportunity, determining what role, if any, computer-based technologies can play in addressing the business need, articulating business requirements for the technology solution, specifying alternative approaches to acquiring the technology capabilities needed to address the business requirements, and specifying the requirements for the information systems solution in particular, in-house development, development from third-party providers, or purchased commercial-off-the-shelf (COTS) packages...."

Based on the course description, it is apparent that students enrolled in the SA\&D course(s) should have a myriad set of both technical and business oriented skills and knowledge. Thus, the aim of this research is to find out if there is consensus between IS professionals and the labor market on the skills and knowledge requirements for entry level system analysts. The answer to this question is important to the prospective students as well as graduating seniors who are getting ready for the job market. The question should also enable those who teach SA\&D to gauge whether they are adequately preparing system analysts to take advantage of the open positions in the job market. The following section provides a brief review of the literature on systems analysts. Thereafter, the research method, analysis, discussion, and conclusions are presented.

\section{Literature Review}

The current Information Systems 2010 (IS2010) model curriculum has designated Systems Analysis and Design (SA\&D) as one of the seven core courses in the IS curriculum (Topi et al., 2010). The designation of SA\&D as a core course is a slight deviation from the previous curricula - IS97 and IS2002 - in which the SA\&D course was closely matched with the Analysis and Logical Design course (Gorgone, Davis, Valacich, Topi, Feinstein \& Longenecker, 2003). The designation and renaming of SA\&D as a core course may be attributed to the ubiquitous, proliferation, and embeddedness nature of IS, both in the business environment and everyday life activities - which calls for graduates skilled in the processes involved in the analysis, design, and implementation of IS. Upon graduation, those students skilled and knowledgeable about the SA\&D processes may pursue careers as business analysts or systems analysts. According to Misic and Graf (2004), a systems analyst is defined as "an individual that solves problems by identifying requirements, suggesting alternative solutions, presenting findings on systems, and maintaining an organizations' system." Specifically, some of the salient roles of systems analysts is planning, designing, and updating computer applications and systems (Haga, Moreno, \& Segal, 2012).

The popularity of an academic course may be determined by a number of factors. Some of these factors include the ease of the course work, social prestige, interest in the course materials, and the potential economic and social payoffs from the job market. According to the Bureau of Labor Statistics - U.S. Department of Labor - Occupational Outlook Handbook (2015), employment of system analysts is projected to grow 25 percent from 2012 to 2022, much faster than the average for all other occupations. Specifically, growth in cloud computing, cybersecurity, mobile networks, and the ubiquitous nature of IS in many daily life activities (Internet of Things) and business processes will drive the demand for system analysts in many organizations (Bureau of Labor Statistics, 2015).

Although IS emerged in the 1950s as a distinct academic discipline and was integrated in the business schools' curricula in the 1960s, the official IS curricula was not published until the late 1970s (Hirschheim \& Klein, 2012; Karanja \& Zaveri, 2012). In spite of the coming of age of the IS, the academic field of IS exists under a variety of different names. The most common titles for 
the IS major at the undergraduate level programs in institutions accredited by the Association to Advance Collegiate Schools of Business (AACSB) in the US are Management Information Systems (41\%), Information Systems (21\%), and Computer Information Systems (18\%) with the remaining 20\% assuming other various titles such as Information Science and Systems, Computer Information Technology, Information Technology and Systems etc. (Pierson, Kruck, \& Teer, 2008).

\section{Prior Systems Analysts Studies}

A number of researchers have investigated various domains that relate to the career prospects of IS graduates. These studies have reported that IS graduates usually tend to work as programmers, network engineers, database administrators, business/system analysts, and business/information technology leaders (Karanja \& Zaveri, 2012). There are also studies that have investigated the skill sets of IS graduates (Downey, McMurtrey, \& Zeltmann, 2008; K. Lee \& Mirchandani, 2010). Specifically, a number of researchers have explored issues relating to systems analysts. For instance, C. K. Lee (2005) sought to find out the up-to-date skill requirements for systems analysts. Based on data from job ads posted on corporate websites of 230 firms in the Fortune 500, the results revealed that Fortune 500 firms expect systems analysts to be multi-skilled (database, functional business, communication, interpersonal, and all phases of IS development-planning, analysis, design, implementation and maintenance).

Elsewhere, Guidry, Stevens, and Totaro (2011) investigated the skills and topics that SA\&D instructors' perceived to be important in the SA\&D course. After surveying the IS faculty in the AACSB accredited schools in the US, the authors reported that IS faculty disagreed on the importance of object oriented analysis and structured analysis in the curriculum in spite of the fact that professors spend more time on these two areas. Also, Guidry and Stevens (2014) sought to find out if there are any differences in how academics and practitioners perceive the SA\&D course. Using a survey of SA\&D faculty at AACSB accredited business schools in the US and practitioners from Canada, UK, South Africa, and 24 states within the US, they found that, practitioners believe that more time should be spent on structured analysis topics. Overall, practitioners and academics agree on approximately $40 \%$ of the SA\&D skills and knowledge areas. Elsewhere, Wang and Wang (2014), suggested a strategy for redesigning the SA\&D course/curriculum and based on a survey of MIS courses offered by the best (based on Businessweek magazine) 62 business schools in the Northeast and South regions in the US, they suggested that, schools should shift their focus to business skills used in system acquisitions instead of just teaching system constructions. In summary, Table 1 shows some of the results from the aforementioned studies as well as others that have sought to investigate various issues related to systems analysts or the SA\&D course.

Table 1: A subset of studies investigating various issues relating to systems analysts.

\begin{tabular}{|c|c|c|c|c|}
\hline Author (s) & Research Goal(s) & Variables & Sampling Method & Results \\
\hline \begin{tabular}{|l} 
Green (1989) \\
\end{tabular} & $\begin{array}{l}\text { Investigate wheth- } \\
\text { er there are percep- } \\
\text { tual differences } \\
\text { among systems } \\
\text { analysts and end } \\
\text { users about how } \\
\text { systems analysts } \\
\text { perform their job } \\
\text { and incentives } \\
\text { mechanisms }\end{array}$ & $\begin{array}{l}\text { Skills, job roles, } \\
\text { no-salary incen- } \\
\text { tives }\end{array}$ & $\begin{array}{l}\text { A survey involving } \\
\text { IS employees based } \\
\text { in the US from } 17 \\
\text { city governments, } 18 \\
\text { state governments, } \\
19 \text { industrial firms, } \\
\text { and } 16 \text { financial } \\
\text { firms ( } 872 \text { question- } \\
\text { naires from } 52 \text { or- } \\
\text { ganizations - } 83.3 \\
\text { percent response } \\
\text { rate) }\end{array}$ & $\begin{array}{l}\text { There are significant differences in how } \\
\text { users and systems analysts perceive the } \\
\text { skills, job roles, and non-salary incen- } \\
\text { tives for systems analysts (e.g. systems } \\
\text { analysts more than users recognize the } \\
\text { importance of behavioral skills for effec- } \\
\text { tive development while the users expect } \\
\text { systems analysts to exhibit technical } \\
\text { skills in situations where behavioral } \\
\text { skills are required) and these differences } \\
\text { are salient both in the public and private } \\
\text { sector }\end{array}$ \\
\hline
\end{tabular}




\begin{tabular}{|c|c|c|c|c|}
\hline Author (s) & Research Goal(s) & Variables & Sampling Method & Results \\
\hline $\begin{array}{l}\text { Noll \& Wil- } \\
\text { kins (2002) }\end{array}$ & $\begin{array}{l}\text { Develops a curric- } \\
\text { ulum review mod- } \\
\text { el for the critical } \\
\text { skills needed for IS } \\
\text { professionals }\end{array}$ & $\begin{array}{l}\text { Rate the im- } \\
\text { portance of } 25 \\
\text { skills needed for } \\
\text { programmers, } \\
\text { analysts and end- } \\
\text { user support per- } \\
\text { sonnel. The } 25 \\
\text { skills were catego- } \\
\text { rized in five major } \\
\text { areas: business } \\
\text { knowledge, ad- } \\
\text { vanced IS applica- } \\
\text { tions, user support, } \\
\text { programming and } \\
\text { systems planning }\end{array}$ & $\begin{array}{l}\text { Survey from } 380 \text { US } \\
\text { companies who re- } \\
\text { cruit IT majors from } \\
\text { the Midwestern Uni- } \\
\text { versity (60 usable } \\
\text { responses from } 76 \text { ). } \\
\text { Also an alumni sur- } \\
\text { vey was sent to } 337 \\
\text { students who gradu- } \\
\text { ated from the Mid- } \\
\text { western University } \\
\text { (56 responded). }\end{array}$ & $\begin{array}{l}\text { Skills in business knowledge were sig- } \\
\text { nificantly different between the analysts } \\
\text { group and the programmer and end-user } \\
\text { support personnel. Business knowledge } \\
\text { skills consistent of } 8 \text { factors that included } \\
\text { knowledge of business functions, oral } \\
\text { and written communication skills, ana- } \\
\text { lytical skills and problem solving }\end{array}$ \\
\hline $\begin{array}{l}\text { Misic \& Graf } \\
(2004)\end{array}$ & $\begin{array}{l}\text { Analyze the most } \\
\text { important tasks } \\
\text { and skills needed } \\
\text { by system analysts }\end{array}$ & $\begin{array}{l}\text { Tasks performed, } \\
\text { skills used }\end{array}$ & $\begin{array}{l}\text { A survey of systems } \\
\text { analysts in the US } \\
\text { (819 firms) was } \\
\text { conducted to assess } \\
\text { what tasks are most } \\
\text { important, and what } \\
\text { skills are most im- } \\
\text { portant with a } 101 \\
(12.3 \%) \text { response } \\
\text { rate }\end{array}$ & $\begin{array}{l}\text { Important tasks-those associated with } \\
\text { traditional system development, (defin- } \\
\text { ing system scope, objectives, systems } \\
\text { requirements, evaluating system impact } \\
\text { and performance). Analytical skills most } \\
\text { important skills followed by technical } \\
\text { and communication skills with least } \\
\text { important skills being interpersonal } \\
\text { skills. }\end{array}$ \\
\hline $\begin{array}{l}\text { Lerouge, } \\
\text { Newton, \& } \\
\text { Blanton, } \\
(2005)\end{array}$ & $\begin{array}{l}\text { Investigate the } \\
\text { knowledge and } \\
\text { skill sets that sys- } \\
\text { tems analysts per- } \\
\text { ceive to be im- } \\
\text { portant }\end{array}$ & $\begin{array}{l}\text { Age, gender, IS } \\
\text { skills (perceptions of } \\
\text { importance, prefer- } \\
\text { ence to use, percep- } \\
\text { tions of importance) }\end{array}$ & $\begin{array}{l}\text { Self-reported survey } \\
\text { data from (124 usa- } \\
\text { ble responses from } \\
158) \text { systems ana- } \\
\text { lysts in } 12 \text { Fortune } \\
500 \text { firms }\end{array}$ & $\begin{array}{l}\text { Although differences exist in perceptions } \\
\text { and preferences across genders and age } \\
\text { groups, overall systems analysts perceive } \\
\text { the requirement for a multi-faceted set of } \\
\text { skills and knowledge (interpersonal skills } \\
\text { and system development skills are } \\
\text { ranked higher than political skills and } \\
\text { knowledge, technology skills, business } \\
\text { task knowledge) and prefer using them }\end{array}$ \\
\hline $\begin{array}{l}\text { C. K. Lee } \\
(2005)\end{array}$ & $\begin{array}{l}\text { Find the up to date } \\
\text { skill requirements } \\
\text { for systems ana- } \\
\text { lysts in Fortune } \\
500 \text { firms }\end{array}$ & $\begin{array}{l}\text { Technical/business } \\
\text { and systems skills } \\
\text { associated with Job } \\
\text { ads (systems ana- } \\
\text { lysts/business ana- } \\
\text { lysts/IS analysts) }\end{array}$ & $\begin{array}{l}\text { Job ads posted on } \\
\text { corporate websites } \\
(902 \text { job ads from } \\
230 \text { firms in the } \\
\text { Fortune } 500)\end{array}$ & $\begin{array}{l}\text { Fortune } 500 \text { firms expect system analysts } \\
\text { to be multi-skilled (database, functional } \\
\text { business, communication, interpersonal, } \\
\text { and all phases of IS development) }\end{array}$ \\
\hline $\begin{array}{l}\text { Banerjee \& } \\
\text { Lin }(2006)\end{array}$ & $\begin{array}{l}\text { Assess the essen- } \\
\text { tial entry-level } \\
\text { skills for systems } \\
\text { analysts }\end{array}$ & Skill sets & $\begin{array}{l}\text { Survey based (23 } \\
\text { responses-55\% re- } \\
\text { sponse rate) data } \\
\text { gathered from high- } \\
\text { level IT practitioners } \\
\text { in various industries } \\
\text { in US }\end{array}$ & $\begin{array}{l}\text { The top four most important techniques } \\
\text { to master for use in gathering require- } \\
\text { ments are document analysis, observa- } \\
\text { tions, individual interviews, and proto- } \\
\text { typing. Structured development tech- } \\
\text { niques (flow charts, data flow diagrams, } \\
\text { ER diagrams, decisions tree/charts), and } \\
\text { software tools (word processing, spread- } \\
\text { sheet, database, diagramming) are the } \\
\text { most important skills. }\end{array}$ \\
\hline
\end{tabular}




\begin{tabular}{|c|c|c|c|c|}
\hline Author (s) & Research Goal(s) & Variables & Sampling Method & Results \\
\hline $\begin{array}{l}\text { McMurtrey, } \\
\text { Downey, } \\
\text { Zeltmann, \& } \\
\text { Friedman } \\
(2008)\end{array}$ & $\begin{array}{l}\text { Determine which } \\
\text { skills are the most } \\
\text { important for en- } \\
\text { try-level IT per- } \\
\text { sonnel }\end{array}$ & $\begin{array}{l}\text { IT skills (which are } \\
\text { more important, do } \\
\text { demographic fac- } \\
\text { tors, managerial } \\
\text { level of type of } \\
\text { organization influ- } \\
\text { ence skill im- } \\
\text { portance percep- } \\
\text { tion) }\end{array}$ & $\begin{array}{l}\text { A survey of } 153 \text { IT } \\
\text { professionals from } 6 \\
\text { organizations in the } \\
\text { mid-South location } \\
\text { of USA }\end{array}$ & $\begin{array}{l}\text { This study illustrated that IT profession- } \\
\text { als perceived both technical and non- } \\
\text { technical as being important. However, } \\
\text { the top six skills (problem-solving, criti- } \\
\text { cal thinking, team, oral communication, } \\
\text { creative thinking, and written communi- } \\
\text { cation) were rated the most important. }\end{array}$ \\
\hline $\begin{array}{l}\text { Yang \& } \\
\text { Cheng (2009) }\end{array}$ & $\begin{array}{l}\text { Investigate the } \\
\text { correlations and } \\
\text { associations be- } \\
\text { tween contextu- } \\
\text { al/personal factors } \\
\text { and creative self- } \\
\text { efficacy of systems } \\
\text { analysts }\end{array}$ & $\begin{array}{l}\text { Personal resources } \\
\text { (computer self- } \\
\text { efficacy, domain- } \\
\text { specific IT skills), } \\
\text { contextual re- } \\
\text { sources (strength } \\
\text { of ties, degree } \\
\text { centrality) creative } \\
\text { self-efficacy }\end{array}$ & $\begin{array}{l}\text { A survey of } 94 \text { (34 } \\
\text { systems analysts and } \\
60 \text { programmers) IS } \\
\text { developers in a Tai- } \\
\text { wanese firm }\end{array}$ & $\begin{array}{l}\text { In regards to systems analyst, the results } \\
\text { indicate that domain specific IT skills } \\
\text { (e.g. systems analysis skills and system } \\
\text { design skills) degree centrality influence } \\
\text { (direct and indirect ties) creative self- } \\
\text { efficacy (creative ideas, innovative prob- } \\
\text { lem solving) although negatively for the } \\
\text { degree centrality }\end{array}$ \\
\hline $\begin{array}{l}\text { Guidry, Ste- } \\
\text { vens, \& Tota- } \\
\text { ro }(2011)\end{array}$ & $\begin{array}{l}\text { Evaluate how the } \\
\text { educators perceive } \\
\text { the important and } \\
\text { coverage of topics } \\
\text { in the SA\&D } \\
\text { courses }\end{array}$ & $\begin{array}{l}\text { Traditional topics, } \\
\text { structured analysis } \\
\text { topics, object ori- } \\
\text { ented topics }\end{array}$ & $\begin{array}{l}\text { A survey of the IS } \\
\text { faculty }(2643) \text { of all } \\
\text { AACSB accredited } \\
\text { schools in the US } \\
(124 \text { usable respons- } \\
\text { es) }\end{array}$ & $\begin{array}{l}\text { Object oriented analysis and structured } \\
\text { analysis exhibited most disagreement on } \\
\text { importance but professors spend more } \\
\text { time on them. More emphasize should be } \\
\text { devoted to UML too }\end{array}$ \\
\hline $\begin{array}{l}\text { Ahmed, } \\
\text { Capretz, \& } \\
\text { Campbell } \\
(2012)\end{array}$ & $\begin{array}{l}\text { Evaluate the de- } \\
\text { mand for soft skills } \\
\text { in software devel- } \\
\text { opment }\end{array}$ & $\begin{array}{l}\text { Soft skills in soft- } \\
\text { ware development }\end{array}$ & $\begin{array}{l}\text { Analysis of } 115 \\
\text { online portals job } \\
\text { advertisements for } \\
\text { systems analyst posi- } \\
\text { tions (Workopo- } \\
\text { lis.ca-US, euro- } \\
\text { jobs.com-Europe, } \\
\text { monsterindia.com- } \\
\text { Asia, seek.com.au- } \\
\text { Australia) }\end{array}$ & $\begin{array}{l}\text { For system analysts, communication } \\
\text { skills, analytical and problem-solving } \\
\text { skills, and team player are in high de- } \\
\text { mand, organizational skills are in moder- } \\
\text { ate demand, while fast learned, ability to } \\
\text { work independently, innovative, inter- } \\
\text { personal skills, and open and adaptable } \\
\text { to changes are in low in demand. }\end{array}$ \\
\hline $\begin{array}{l}\text { Powell \& } \\
\text { Yager (2013) }\end{array}$ & $\begin{array}{l}\text { Determine what } \\
\text { practitioners think } \\
\text { should be taught in } \\
\text { an introductory } \\
\text { SA\&D course }\end{array}$ & \begin{tabular}{|l|} 
Skills, tools, de- \\
velopment practic- \\
es, development \\
methodologies
\end{tabular} & $\begin{array}{l}\text { A survey of } 120 \text { US } \\
\text { based firms with } 100 \\
\text { responding ( } 83 \% \\
\text { response rate) }\end{array}$ & $\begin{array}{l}\text { Two type of skills-working in teams and } \\
\text { working with end-users and two type of } \\
\text { tools, namely, estimation of critical path } \\
\text { for tasks and project scope statement } \\
\text { emerged as the most critical for systems } \\
\text { analysts }\end{array}$ \\
\hline $\begin{array}{l}\text { Guidry \& } \\
\text { Stevens } \\
(2014)\end{array}$ & $\begin{array}{l}\text { Investigate if there } \\
\text { are any differences } \\
\text { in how academics } \\
\text { and practitioners } \\
\text { perceive the } \\
\text { SA\&D course }\end{array}$ & $\begin{array}{l}\text { Important topics in } \\
\text { the courses, } \\
\text { amount spent } \\
\text { teaching each topic } \\
\text { in the course }\end{array}$ & $\begin{array}{l}\text { Survey of SA\&D } \\
\text { faculty (124 usable } \\
\text { responses) at } \\
\text { AACSB accredited } \\
\text { business schools in } \\
\text { the US and } 98 \text { prac- } \\
\text { titioners (Canada, } \\
\text { UK, South Africa, } \\
\text { and } 24 \text { states within } \\
\text { the US) }\end{array}$ & $\begin{array}{l}\text { Practitioners believe more time should } \\
\text { be spent on structured analysis topics. } \\
\text { Overall, practitioners and academics } \\
\text { agree on approximately } 40 \% \text { of the } \\
\text { SA\&D skills and knowledge areas (e.g. } \\
\text { traditional topics to be emphasized in- } \\
\text { clude interface design, file and database } \\
\text { design, program design and structured } \\
\text { analysis and object oriented analysis) }\end{array}$ \\
\hline
\end{tabular}




\begin{tabular}{|l|l|l|l|l|}
\hline Author (s) & Research Goal(s) & \multicolumn{1}{|c|}{ Variables } & Sampling Method & \multicolumn{1}{|c|}{ Results } \\
\hline $\begin{array}{l}\text { Wang \& } \\
\text { Wang (2014) }\end{array}$ & $\begin{array}{l}\text { Suggest a strategy } \\
\text { for redesigning the } \\
\text { SA\&D } \\
\text { course/curriculum }\end{array}$ & $\begin{array}{l}\text { Managerial signifi- } \\
\text { cance, analysis and } \\
\text { design skills, doc- } \\
\text { umentation }\end{array}$ & $\begin{array}{l}\text { A survey of MIS } \\
\text { courses offered by } \\
\text { the best (based on } \\
\text { Businessweek maga- } \\
\text { zine) 62 business } \\
\text { schools in the North- } \\
\text { east and South re- } \\
\text { gions in the US }\end{array}$ & $\begin{array}{l}\text { Refocus on business skills used in sys- } \\
\text { tem acquisitions (planning, scope devel- } \\
\text { opment, linking IS and business strategy, } \\
\text { oral communication, writing skills, team } \\
\text { work etc.) instead of just system con- } \\
\text { structions skills (planning, analysis, and } \\
\text { design) }\end{array}$ \\
\hline $\begin{array}{l}\text { This study } \\
\text { industry wants } \\
\text { (skills and } \\
\text { knowledge re- } \\
\text { quirements) for } \\
\text { entry level system } \\
\text { analysts }\end{array}$ & $\begin{array}{l}\text { Find out what the } \\
\text { gegree type, de- } \\
\text { experience, tech- } \\
\text { nical/non-technical } \\
\text { skills, certifica- } \\
\text { tions }\end{array}$ & $\begin{array}{l}\text { A content analysis of } \\
\text { 200 systems ana- } \\
\text { lysts'online job } \\
\text { advertisements and a a } \\
\text { survey of 20 senior } \\
\text { IS professionals }\end{array}$ & $\begin{array}{l}\text { Employers prefer entry level systems } \\
\text { analysts with an undergraduate Comput- } \\
\text { er Science degree, have some years of } \\
\text { experience, have some certifications, } \\
\text { have non-technical and people (problem } \\
\text { solving and oral communication) skills }\end{array}$ \\
\hline
\end{tabular}

Although the studies in Table 1 are not a comprehensive list, they are indicative of the efforts that have been devoted in trying to understand the various concepts associated with systems analysts. Usually, research studies targeted at system analysts have tended to assume one of three main research streams, namely, what to teach in a SA\&D courses, how to teach a SA\&D course, and the knowledge, skills, and tools required of SA\&D graduates. In each of these research streams, researchers have tended to collect data mainly from surveying alumni, professionals in the industry, or online job advertisements. This study contributes to the SA\&D body of knowledge by seeking to determine the skills sets that are important for an entry-level systems analyst. In addition to the currency of the data, the study deviates from some of the prior studies in that it uses data triangulation to empirically compare the results from job advertisement to the views of IS professionals. Also, based on our review of academic research there is a dearth of research studies that investigates the type of degree (Computer Science, Information Science, Information Systems etc.), level of degree (associate, bachelors, masters, etc.), years of experience and the type of industry certifications needed of entry level systems analysts. This study aims at narrowing this gap.

\section{The Role of the Systems Analyst}

As previously stated, systems analysts are an integral part of many organizations because of their ability to solve business problems by identifying the requirements, presenting findings, suggesting alternative solutions, and maintaining an organization's systems (Misic \& Graf, 2004). Given the multifaceted (technical, business, and people/soft skills) and dynamic nature - due to the constant change in the IS artifacts - of the role and job functions of a systems analyst, there is an ongoing debate over the skills needed to be an effective systems analyst (Ahmed, Capretz, \& Campbell, 2012; Joseph et al., 2010). According to Woratscheck and Lenox (2007), education and prior work experience are important for both entry level and experienced systems analyst. Also, the quality of education that systems analysts receive can determine the level of expertise they will have when they enter the workforce (Guidry \& Stevens, 2014; Woratschek \& Lenox, 2002).

Universities teach aspiring systems analysts important traditional job skills such as gathering requirements, designing and developing systems, managing resources, and performing quality reviews and system(s) testing (Banerjee \& Lin, 2006). However, since many companies are now exploring outsourcing and software as a service, systems analysts must be equipped with a wider business-oriented educational background beyond the traditional technical skills (Joseph et al., 2010; Wang \& Wang, 2014). With the concept of a flattened world in mind (Friedman, 2006), 
many IS programs focus on a broad curriculum that prepares students, not only for local or regional organizations but also, for multinational and cross-border/global organizations (Banerjee \& Lin, 2006). Thus, due to the evolving nature of the systems analyst's role and its importance in the IS organization, educational institutions should partner with global firms in developing a global oriented skill set for systems analysts.

Many organizations are implementing IS into their business models either as a result of countering industry competitive moves (linking brick and mortal store-fronts with online platforms), integrating previously disparate organizational units (using Enterprise Resource Planning or Supply Chain Management systems), cutting costs and streamlining operations (use of robots and automated value chain systems) or as a tool to facilitate the capturing of a wider and evolving market segment (integrating social media and web 2.0 tools into the business processes). The aforementioned systems entail software developments, support of enterprise resource planning software, the use of business analysis for organizations, auditing, compliance, information security, and web development (Satzinger \& Jackson, 2012). As a result, there is a growing demand for employees with the requisite skills and knowledge on how to develop and integrate these systems into the organizational value chains (Joseph et al., 2010). Thus, the role of the systems analyst continues to evolve and grow at a rapid rate, and, according to $\mathrm{Ku}(2014)$, the systems analyst is among the fastest growing professions with approximately 300,000 new jobs expected by 2018 .

In the past, there has been a known disconnect between industry needs and academic preparation for IS employees (Banerjee \& Lin, 2006). For instance, the existence of a broad number of platforms and tools that organizations adopt and the lack of coordination in teaching these platforms and tools at the university level has been cited as one of the causes of this disconnect. To counter this disconnect, universities have been constantly trying to align their programs both to the local and the national job markets by engaging IS practitioners as advisors (Thiele, 2014). Moreover, IS practitioners provide balance and direction on curriculum design/redesign, emerging industry innovations, as well as avenues for internships and job opportunities.

In this study, the authors gathered data from the IS professionals who were working as systems analysts as well as online job advertisements for the entry level systems analyst positions. The goal of the study was to evaluate the skills and knowledge that are perceived to be the most important for the entry level systems analysts position. Thus, in this study, the research premise is that the relative proportions of one variable are homogeneous with the second variable. For instance, for the years of experience, the ideal results should be that the proportional values obtained from the IS professionals should be statistically similar to those obtained from the online job advertisements.

\section{Research Method}

The scope of this research study will be limited to the skill sets of entry level systems analysts working in the US. The objective of this study is to determine the skill sets that are important for an entry-level systems analyst. This study used two sources of data, namely, (1) content analysis of online systems analysts job advertisements and (2) a survey of IS professionals. To start, an evaluation of the online job advertisements posted in three popular websites, namely, Careerbuilder.com (18 million unique monthly visitors), Monster.com ( 8 million unique monthly visitors), and Indeed.com (5 million unique monthly visitors) during the period of March-June 2014 was done. Although this is not an exhaustive list, these websites have been consistently ranked in the top list for best websites for job searches (Adams, 2013; Griffith, 2015).

A total of 200 entry level systems analysts job advertisements were downloaded and evaluated to determine the skills employers wanted in an applicant. Various variants of the "information systems/business analyst" job titles were used and the corresponding salient skill sets identified. The 
major factors when evaluating job ads were degree type, degree level, years of experience, technical skills, non-technical skills, and the need for certifications. The comparative list of the specific technical and non-technical skill sets was first obtained from the IS 2010 model curriculum (Topi et al., 2010) and other prior studies (McMurtrey, Downey, Zeltmann \& Friedman, 2008; Misic \& Graf, 2004; Noll \& Wilkins, 2002). A specific skill set such as 'oral communication', was retained if it had more than 20 occurrences in the job advertisement. For the purpose of this study, a degree type is defined as either IS or Computer Science. The degree level is defined as a bachelor's degree or master's degree. Due to the nature of this study and the data collected, associate's degrees were excluded. Once these skill sets were identified in the job advertisements, the most common ones were used in the second stage of the data collection/validation with the survey of 20 senior level IS professionals.

The 20 senior level IS professionals were selected based on a purposeful sampling method (Patton, 1990). The IS professionals worked for five multi-billion dollar organizations based in the Northeast US. The organizations where these IS professionals worked are known for hiring systems analysts and are also known for engaging in major software applications development and project/change management initiatives. The IS professionals (participants) have both managerial and mentoring experience for new systems analysts in their organizations which serves to expose them to the skill sets possessed by new graduates and entry level systems analysts. Data was collected from the IS professionals using a survey instrument. The survey instrument which was based on a five-level Likert item ranging from strongly agree, to strongly disagree was pretested for validity and reliability and contained questions generated from the main categories gathered from the online entry level systems analysts' job advertisements. The survey instrument was distributed to the senior level IS professionals and out of the 20 senior levels IS professionals that received a survey instrument, all 20 responded. Although the sample size may appear to be small, it is homogenous and brings together people with similar backgrounds and experiences which reduces variations, simplifies analysis, and facilitates group consensus akin to a focus group (Nastasi, 1998).

\section{Results}

\section{Type of Degree}

In order to access the skills that are important for an entry-level systems analyst, this study examined two sources of data: 200 systems analysts' job advertisements, and a survey of 20 Senior IS professionals. Table 2, section A, shows a comparative summary of the data obtained from the job advertisements and the survey of Senior IS professionals. To carry out the analysis, and considering the unavailability of data points in the 'No specification' category (under the 20 Senior IS professionals column), the 'No specification' category was eliminated yielding the usable sample size shown in Table 2, section B. The cleaned data, as shown in part B, was better suited to a Chi-square test and yielded the results shown below.

From the results, there are no significant statistical differences between the opinions of the IS professionals, who prefer a computer science undergraduate degree for entry level systems analysts, and the requirements included in the entry level systems analysts job advertisements. 
Table 2: Type of degree desired of system analysts.

\begin{tabular}{|c|c|c|c|c|c|}
\hline \multicolumn{6}{|c|}{ Type of degree } \\
\hline \multicolumn{6}{|c|}{ (A) } \\
\hline \multicolumn{3}{|c|}{200 Job advertisements } & \multicolumn{3}{|c|}{20 Senior IS professionals } \\
\hline Category & \# & $\%$ & Category & \# & $\%$ \\
\hline Computer Science & 140 & $70 \%$ & Computer Science & 16 & $80 \%$ \\
\hline Information Systems & 38 & $19 \%$ & Information Systems & 4 & $20 \%$ \\
\hline No specification & 22 & $11 \%$ & No specification & 0 & $0 \%$ \\
\hline Total & 200 & $100 \%$ & Total & 20 & $100 \%$ \\
\hline \multicolumn{6}{|c|}{ (B) } \\
\hline \multicolumn{3}{|c|}{200 Job advertisements } & \multicolumn{3}{|c|}{20 Senior IS professionals } \\
\hline Category & $\#$ & $\%$ & Category & \# & $\%$ \\
\hline Computer Science & 140 & $70 \%$ & Computer Science & 16 & $80 \%$ \\
\hline Information Systems & 38 & $19 \%$ & Information Systems & 4 & $20 \%$ \\
\hline Total & 178 & $89 \%$ & Total & 20 & $100 \%$ \\
\hline \multicolumn{6}{|c|}{$x^{2}$ test results } \\
\hline$X^{2}=0.02$ & \multicolumn{2}{|c|}{ Alpha $=0.05$} & \multicolumn{2}{|l|}{ Degree of freedom $=1$} & $=0.889$ \\
\hline \multicolumn{3}{|c|}{ Pearson's C (effect size measure) $=0.01$} & \multicolumn{3}{|c|}{ Estimated power $(1-\beta)=0.034$} \\
\hline
\end{tabular}

\section{Degree Level}

Table 3, section A, shows the categories and the corresponding values obtained from the IS professionals' survey and the job advertisements. Likewise (as in Table 2), to facilitate the statistical analysis using a Chi-Square test, Table 3, section A, was regenerated after dropping the No degree category due to low values in the IS professionals' response group and also to conform to the $2 \mathrm{X} 2$ contingency table format.

The results of the Chi-square statistical tests shown in Table 3, section B, indicate that there is a statistically significant difference between the opinions of the IS professionals and the information contained in the job advertisements as far as the degree level of education for entry-level systems analysts is concerned. IS professionals responded that a master's degree is desirable for a systems analyst, while the job advertisements called for a bachelor's degree. There were job advertisements ( 35 or 17.5\%) which never specified the need for any formal college education (no degree(s) were indicated in the job advertisements) as shown in Table 3, section A. 
Table 3: Degree level desired of system analysts.

\begin{tabular}{|c|c|c|c|c|c|}
\hline \multicolumn{6}{|c|}{ Degree level } \\
\hline \multicolumn{6}{|c|}{ (A) } \\
\hline \multicolumn{3}{|c|}{200 Job advertisements } & \multicolumn{3}{|c|}{20 Senior IS professionals } \\
\hline Category & $\#$ & $\%$ & Category & \# & $\%$ \\
\hline Bachelor's degree & 138 & $69 \%$ & Bachelor's degree & 7 & $35 \%$ \\
\hline Master's degree & 27 & $13.5 \%$ & Master's degree & 13 & $65 \%$ \\
\hline No degree & 35 & $17.5 \%$ & No degree & 0 & $0 \%$ \\
\hline Total & 200 & $100 \%$ & Total & 20 & $100 \%$ \\
\hline \multicolumn{6}{|c|}{ (B) } \\
\hline \multicolumn{3}{|c|}{200 Job advertisements } & \multicolumn{3}{|c|}{20 Senior IS professionals } \\
\hline Category & $\#$ & $\%$ & Category & \# & $\%$ \\
\hline Bachelor's degree & 138 & $69 \%$ & Bachelor's degree & 7 & $35 \%$ \\
\hline Master's degree & 27 & $13.5 \%$ & Master's degree & 13 & $65 \%$ \\
\hline Total & 165 & $82.5 \%$ & Total & 20 & $100 \%$ \\
\hline \multicolumn{6}{|c|}{$x^{2}$ test results } \\
\hline $\mathrm{X}^{2}=24.899$ & Alpha $=0.05$ & \multicolumn{2}{|c|}{ Degree of freedom $=1$} & \multicolumn{2}{|c|}{ Prob. $=0.001$} \\
\hline \multicolumn{3}{|c|}{ Pearson's C (effect size measure) $=0.344$} & \multicolumn{3}{|c|}{ Estimated power $(1-\beta)=0.999$} \\
\hline
\end{tabular}

\section{Years of Experience}

Table 4, section A, shows a comparative summary of the data obtained from the survey of the IS professionals and the data obtained from the job advertisements. To carry out the analysis, the '23 ' years and the ' $3>$ ' years categories were collapsed into one row while the ' $0-1$ ' year's category was eliminated due to limited data points. The resulting table shown (Table 4 section B) was more appropriate for a Chi-square test and yielded the corresponding results.

From Table 4 Section B, the Chi-square test did not show a significant difference between the IS professionals opinions and the information contained in the job advertisements. As a robustness test, The Fisher exact test was carried out for the data in Table 2, Table 3, and Table 4 and all the tests yielded results that were not statistically different from the Chi-square test results and lead to similar conclusions. 
Table 4: Years of experience of system analysts.

\begin{tabular}{|c|c|c|c|c|c|}
\hline \multicolumn{6}{|c|}{ Years of experience } \\
\hline \multicolumn{6}{|c|}{ (A) } \\
\hline \multicolumn{3}{|c|}{200 Job advertisements } & \multicolumn{3}{|c|}{20 Senior IS professionals } \\
\hline Category & \# & $\%$ & Category & $\#$ & $\%$ \\
\hline 0 -1 years & 2 & $1 \%$ & $0-1$ years & 0 & $0 \%$ \\
\hline $1-2$ years & 31 & $15.5 \%$ & $1-2$ years & 3 & $15 \%$ \\
\hline $2-3$ years & 157 & $78.5 \%$ & $2-3$ years & 16 & $80 \%$ \\
\hline $3>$ years & 10 & $5 \%$ & $3>$ years & 1 & $5 \%$ \\
\hline Total & 200 & $100 \%$ & Total & 20 & $100 \%$ \\
\hline \multicolumn{6}{|c|}{ (B) } \\
\hline \multicolumn{6}{|c|}{ Years of experience } \\
\hline \multicolumn{3}{|c|}{200 Job advertisements } & \multicolumn{3}{|c|}{20 Senior IS professionals } \\
\hline Category & \# & $\%$ & Category & \# & $\%$ \\
\hline $1-2$ years & 31 & $15.5 \%$ & $1-2$ years & 3 & $15 \%$ \\
\hline $2-3$ years & 167 & $78.5 \%$ & $2-3$ years & 17 & $80 \%$ \\
\hline Total & 198 & $94 \%$ & Total & 20 & $100 \%$ \\
\hline \multicolumn{6}{|c|}{$x^{2}$ test results } \\
\hline $\mathrm{X}^{2}=0.006$ & Alpha $=0.05$ & \multicolumn{2}{|c|}{ Degree of freedom $=1$} & \multicolumn{2}{|c|}{ Prob. $=0.939$} \\
\hline \multicolumn{3}{|c|}{ Pearson's C (effect size measure $)=0.005$} & \multicolumn{3}{|c|}{ Estimated power $(1-\beta)=0.03$} \\
\hline
\end{tabular}

\section{Technical Skills}

From the survey results, there were no respondents that indicated that they were either neutral or disagreed with any of the items. The results corresponded to the three entries associated with the strongly agree, agree, and strongly disagree. Table 5, section A, displays the results of the data obtained from the IS professionals and the job advertisements. For simplicity and to facilitate statistical tests (comparing proportions using Z-tests) the results from strongly agree and agree are congregated into one category and the strongly disagree values are dropped from the analysis as shown in Table 5, part B. There are two tests that are performed for each category between the data from the IS professionals (strongly agree, strongly agree + agree) and the data from the online job advertisements.

For the most part, Table 5, section A, shows that the IS professionals agree on system analysts having the five stated technical skills, namely, definition of scope, experience with System Development Life Cycle (SDLC), joint application design, documentation analysts, and prototyping. However, on further review, there is a marked difference in the number of IS professionals who strongly agree (4) and agree (16) with the need for system analysts to have experience with SDLC. Also, there is a sizeable number of IS professionals (25\%) who agree that system analysts should be skilled in joint application design while $75 \%$ strongly agree. 
Entry Level Systems Analysts: What Does the Industry Want?

Table 5: Technical skills desired of system analysts.

\begin{tabular}{|c|c|c|c|c|c|c|c|c|}
\hline \multicolumn{9}{|c|}{ Technical skills } \\
\hline \multicolumn{9}{|c|}{ (A) } \\
\hline \multicolumn{3}{|c|}{200 Job advertisements } & \multicolumn{6}{|c|}{20 Senior IS professionals } \\
\hline & & & \multicolumn{2}{|c|}{ Strongly agree } & \multicolumn{2}{|c|}{ Agree } & \multicolumn{2}{|c|}{ Strongly disagree } \\
\hline Category & \# & $\%{ }^{* a}$ & \# & $\%$ & \# & $\%$ & $\#$ & $\%$ \\
\hline Definition of scope & 110 & $56 \%$ & 17 & $85 \%$ & 3 & $15 \%$ & 0 & $0 \%$ \\
\hline Experience with SDLC & 76 & $38 \%$ & 4 & $20 \%$ & 16 & $80 \%$ & 0 & $0 \%$ \\
\hline Joint application design & 62 & $32 \%$ & 15 & $75 \%$ & 5 & $25 \%$ & 0 & $0 \%$ \\
\hline Documentation analyst & 44 & $22 \%$ & 18 & $90 \%$ & 2 & $10 \%$ & 0 & $0 \%$ \\
\hline Prototyping & 40 & $20 \%$ & 16 & $80 \%$ & 2 & $10 \%$ & 2 & $10 \%$ \\
\hline \multicolumn{9}{|c|}{ (B) } \\
\hline \multicolumn{3}{|c|}{200 Job advertisements } & \multicolumn{6}{|c|}{20 Senior IS professionals } \\
\hline & & & \multicolumn{3}{|c|}{ Strongly agree } & \multicolumn{3}{|c|}{ Strongly agree + Agree } \\
\hline Category & \# & $\%$ & \# & $\%$ & & & \# & $\%$ \\
\hline \multirow[t]{2}{*}{ Definition of scope } & 110 & $56 \%$ & 17 & $85 \%$ & & & 20 & $100 \%$ \\
\hline & \multicolumn{5}{|c|}{$\begin{array}{l}Z \text {-value }=-2.511 \text {, proportions signifi- } \\
\text { cantly different at } 0.05, p=0.013\end{array}$} & \multicolumn{3}{|c|}{$\begin{array}{l}Z \text {-value }=-3.830, \text { proportions signifi- } \\
\text { cantly different at } 0.01, p=0.001\end{array}$} \\
\hline & & & \multicolumn{3}{|c|}{ Strongly agree } & \multicolumn{3}{|c|}{ Strongly agree + Agree } \\
\hline & \# & $\%$ & \# & $\%$ & & & \# & $\%$ \\
\hline \multirow[t]{4}{*}{ Experience with SDLC } & 76 & $38 \%$ & 4 & $20 \%$ & & & 20 & $100 \%$ \\
\hline & \multicolumn{5}{|c|}{$\begin{array}{l}\text { Z-value }=1.596, \text { proportions not signif- } \\
\text { icantly different, } p=0.112\end{array}$} & \multicolumn{3}{|c|}{$\begin{array}{l}\text { Z-value }=-5.331 \text {, proportions signifi- } \\
\text { cantly different at } 0.01, p=0.001\end{array}$} \\
\hline & & & \multicolumn{3}{|c|}{ Strongly agree } & \multicolumn{3}{|c|}{ Strongly agree + Agree } \\
\hline & \# & $\%$ & \# & $\%$ & & & $\#$ & $\%$ \\
\hline \multirow[t]{2}{*}{ Joint application design } & 62 & $32 \%$ & 15 & $75 \%$ & & & 20 & $100 \%$ \\
\hline & \multicolumn{5}{|c|}{$\begin{array}{l}Z \text {-value }=-3.822, \text { proportions signifi- } \\
\text { cantly different at } 0.01, p=0.001\end{array}$} & \multicolumn{3}{|c|}{$\begin{array}{l}\text { Z-value }=-5.968, \text { proportions signifi- } \\
\text { cantly different at } 0.01, p=0.001\end{array}$} \\
\hline & & & \multicolumn{3}{|c|}{ Strongly agree } & \multicolumn{3}{|c|}{ Strongly agree + Agree } \\
\hline & \# & $\%$ & \# & $\%$ & & & $\#$ & $\%$ \\
\hline \multirow[t]{2}{*}{ Documentation analyst } & 44 & $22 \%$ & 18 & $90 \%$ & & & 20 & $100 \%$ \\
\hline & \multicolumn{5}{|c|}{$\begin{array}{l}Z \text {-value }=-6.445 \text {, proportions signifi- } \\
\text { cantly different at } 0.01, p=0.001\end{array}$} & \multicolumn{3}{|c|}{$\begin{array}{l}Z \text {-value }=-7.323 \text {, proportions signifi- } \\
\text { cantly different at } 0.01, p=0.001\end{array}$} \\
\hline
\end{tabular}




\begin{tabular}{|c|c|c|c|c|c|c|}
\hline & & & Stron & ree & Strongly a & \\
\hline & \# & $\%$ & \# & $\%$ & $\#$ & $\%$ \\
\hline Prototyping & 40 & $20 \%$ & 16 & $80 \%$ & 18 & $90 \%$ \\
\hline & $\begin{array}{l}\text { Z-val } \\
\text { cantly }\end{array}$ & $\begin{array}{l}=-5.87 \\
\text { ifferen }\end{array}$ & $\begin{array}{l}3 \text {, prop } \\
\text { at } 0.01\end{array}$ & $\begin{array}{l}\text { signifi- } \\
01\end{array}$ & $\begin{array}{l}Z \text {-value }=-6 \\
\text { cantly diffe }\end{array}$ & $\begin{array}{l}\text { ons signifi- } \\
=0.001\end{array}$ \\
\hline $\begin{array}{l}\%^{* a} \text { the value } \\
\text { indicates that th } \\
\text { analyzed }\end{array}$ & $\begin{array}{l}\text { le tota } \\
\text { b adv }\end{array}$ & $\begin{array}{l}\mathrm{b} \text { adv } \\
\text { emer }\end{array}$ & $\begin{array}{l}\text { rtisem } \\
\text { s that }\end{array}$ & $\begin{array}{l}\text { ch that } \\
\text { cally lis }\end{array}$ & $\begin{array}{l}\text { alue for the } \\
\text { his requiren }\end{array}$ & $\begin{array}{l}\text { cope }(110) \\
200 \text { jobs }\end{array}$ \\
\hline
\end{tabular}

When comparing the responses from the IS professionals with the data from the job advertisements, as shown in Table 5, the results reveal statistically significant differences with the exception of the data comparing the strongly agree results from the IS professionals with the job advertisements data for experience with SDLC category.

\section{Non-Technical Skills}

Table 6, section A, shows what seems to be consensus on the IS professionals about the need for systems analysts to have the three non-technical skills, namely, oral communication, problem solving, and attention to detail. On the other hand, these skills were not emphasized in most of the job advertisements as illustrated by the low ratios, namely, $14 \%, 22 \%$, and $11 \%$ for the oral communication, problem solving, and attention to detail respectively. Since the IS professionals seem to agree on the need for these skills, the Z-tests are done against one group of data (Strongly agree) in the job advertisement's data for each category unlike the case with the technical skills data analysis shown in Table 5, section $\mathrm{B}$. The results of the Z-tests for comparing proportions are shown in Table 6 , section B, for each category and show statistically significant differences between the two data sets.

Table 6: Non-technical skills required of systems analysts.

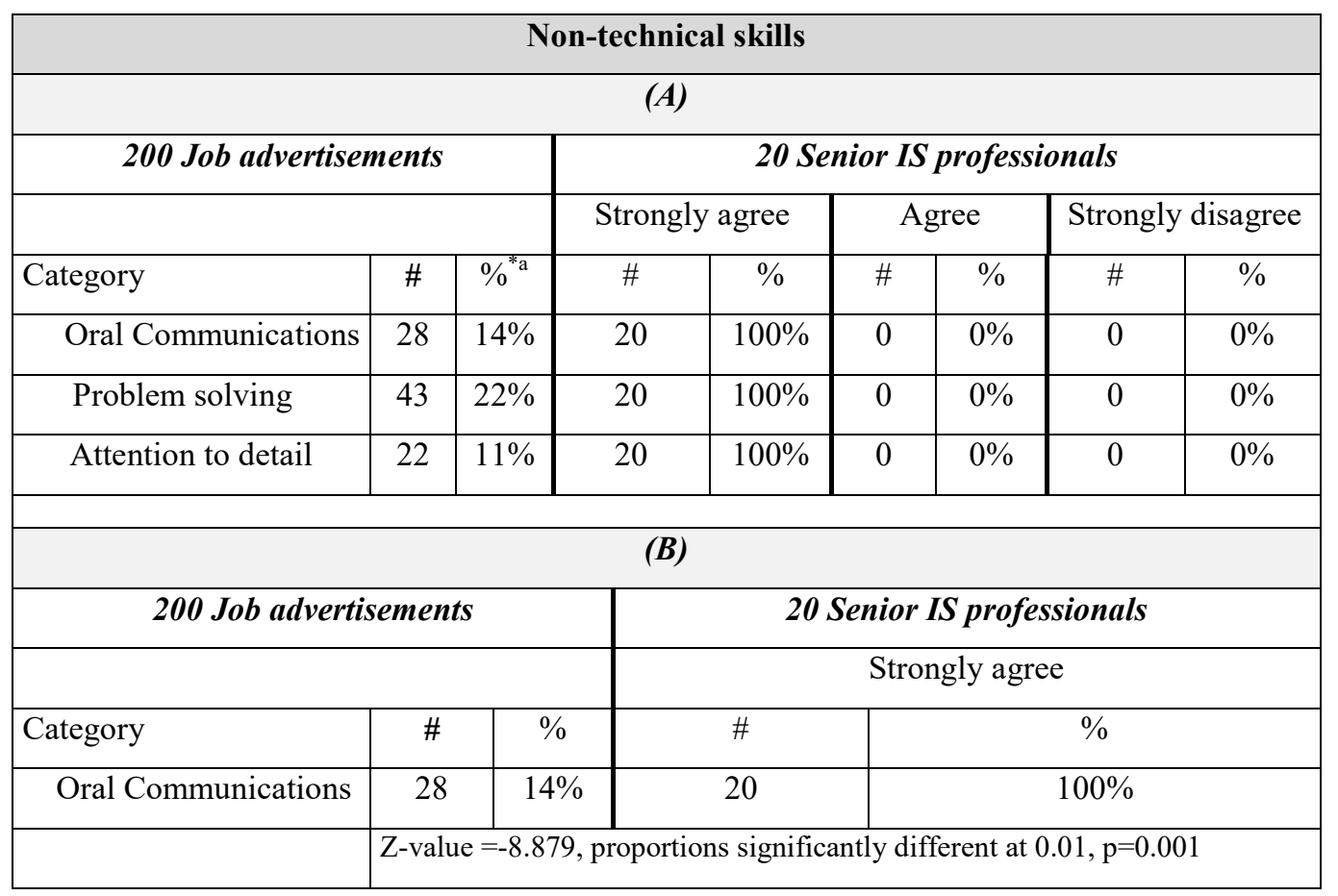




\begin{tabular}{|c|c|c|c|c|}
\hline & \# & $\%$ & \# & $\%$ \\
\hline \multirow[t]{3}{*}{ Problem solving } & 43 & $22 \%$ & 20 & $100 \%$ \\
\hline & \multicolumn{4}{|c|}{ Z-value $=-7.323$, proportions significantly different at $0.01, p=0.001$} \\
\hline & \# & $\%$ & \# & $\%$ \\
\hline \multirow[t]{2}{*}{ Attention to detail } & 22 & $11 \%$ & 20 & $100 \%$ \\
\hline & \multicolumn{4}{|c|}{$\mathrm{Z}$-value $=-9.656$, proportions significantly different at $0.01, \mathrm{p}=0.001$} \\
\hline \multicolumn{5}{|c|}{$\begin{array}{l}\%^{* a} \text { The } 14 \% \text { value for the oral communication is based on the } 28 \text { job advertisements which specifically } \\
\text { stated the need for a systems analyst to be good at oral communication out of the total } 200 \text { job advertise- } \\
\text { ments }\end{array}$} \\
\hline
\end{tabular}

\section{Need for Certifications}

There were not many job advertisements that specified the need for industry certifications as shown by the low numbers ( 22 out of 200 ). As shown in Table 7, section B, the Z-tests indicated that there are significant differences between IS professionals and job advertisement's. The IS professionals are of the opinion that systems analysts should have some form of IT industry certifications. Half of the IS professionals (50\%) indicated the need for systems analysts to be certified while $30 \%$ remained neutral, and $20 \%$ strongly disagreed with the need for certification.

Table 7: Need for systems analyst to have certifications.

\begin{tabular}{|c|c|c|c|c|c|c|c|c|}
\hline \multicolumn{9}{|c|}{ Certifications } \\
\hline \multicolumn{9}{|c|}{ (A) } \\
\hline \multicolumn{3}{|c|}{200 Job advertisements } & \multicolumn{6}{|c|}{20 Senior IS professionals } \\
\hline & & & \multicolumn{2}{|c|}{ Strongly agree } & \multicolumn{2}{|c|}{ Agree } & \multicolumn{2}{|c|}{ Strongly disagree } \\
\hline \multirow[t]{2}{*}{ Category } & \# & $\%{ }^{* a}$ & \# & $\%$ & $\#$ & $\%$ & \# & $\%$ \\
\hline & 22 & $11 \%$ & 10 & $50 \%$ & 6 & $30 \%$ & 4 & $20 \%$ \\
\hline \multicolumn{9}{|c|}{ (B) } \\
\hline & & & \multicolumn{2}{|c|}{ Strongly agree } & \multicolumn{4}{|c|}{ Strongly agree + Agree } \\
\hline Category & \# & $\%{ }^{* a}$ & \# & $\%$ & & $\neq$ & & \\
\hline \multirow[t]{2}{*}{ Certification } & 22 & $11 \%$ & 10 & $50 \%$ & & 6 & & \\
\hline & \multicolumn{4}{|c|}{$\begin{array}{l}\text { Z-value }=-4.717, \text { proportions signifi- } \\
\text { cantly different at } 0.01, p=0.001\end{array}$} & \multicolumn{4}{|c|}{$\begin{array}{l}Z \text {-value }=-7.783 \text {, proportions signifi- } \\
\text { cantly different at } 0.01, p=0.001\end{array}$} \\
\hline \multicolumn{9}{|c|}{$\begin{array}{l}\%{ }^{* a} \text { The } 11 \% \text { value is based on the } 22 \text { out of } 200 \text { job advertisements that specified that the } \\
\text { applicant should possess a certification. }\end{array}$} \\
\hline
\end{tabular}

\section{Discussion}

From Table 2, out of the 20 IS professionals, $16(80 \%)$ of them agreed that system analysts should possess a degree in Computer Science, which was very close to the results from the job advertisements at $70 \%$. The results indicating the need for an entry level systems analyst to have 
an IS undergraduate degree was $20 \%$ and $19 \%$ for the IS professionals and the job advertisements respectively. This could be a direct correlation to the technical skills that job seekers are looking for, since IS students have traditionally received a more balanced technical and non-technical oriented education.

The low numbers for an IS undergraduate degree were surprising because 'systems analyst' is listed as one of the top professions for IS degree seekers (Joseph et al., 2010). The fact that Computer Science majors are identified as the desired degree more often when compared to the IS majors does not explain the disconnect between educational background and required job skills. Recruiters often seek employees who possess both technical and non-technical skills and may find that Computer Science majors have superior technical skills while IS graduates excel in nontechnical skills. The consensus is that a systems analyst should be well rounded and knowledgeable in a variety of areas, and should possess both technical and non-technical skills (McMurtrey et al., 2008)

In what seems like efforts to address the low number of IS graduates as systems analysts, the IS 2010 model curriculum has designated SA\&D as one of the core courses in the IS curriculum with designing and implementing IS solutions being one of the targeted IS specific knowledge and skills (Topi et al., 2010). The architecture of the IS model curriculum is also set in such a way that an IS graduate who takes SA\&D will gain knowledge and skills suited to an application developer, business analyst, and business process analysts among others. The IS 2010 model curriculum's suggested skills involved in designing and implementing IS solutions such as defining scope, systems requirements, evaluating system impact and performance have been found to be important tasks and skills for systems analysts (Misic \& Graf, 2004).

On the other hand, from Table 3, IS professionals indicated that they preferred a system analyst to have a master's degree (65\%) compared to a bachelor's degree (35\%). The aforementioned figures were significantly different from the job advertisements whereby the top preferences were a bachelor's degree (69\%) and masters (14\%). Perhaps, the IS professionals are of the opinion that a system analyst would be more knowledgeable in their duties if they possessed a master's degree. Also, since the IS professionals that participated in the study have been in the industry for quite some time, they may have had opportunities to interact and work with entry level systems analysts and they may have concluded that the most effective systems analysts are those that have earned a master's degree.

From Table 4, after analyzing the years of experience, the IS professionals seem to agree with the data from the job advertisements for a 2-3 years of experience ( $79 \%$ for the job advertisements vs $80 \%$ for the IS professionals). Surprisingly, the job advertisements indicated that the positions were entry level. Thus, IS programs have to work towards getting their students internships as well as through real world class projects that mimic what happens in the real world to account for the experience.

The IS professionals agreed with the need for systems analyst to have the three specified nontechnical skills as shown in Table 5, namely, oral communication, problem solving, and attention to detail. In systems and application developments, systems analysts play key roles that include working closely with users, other IS personnel, project or group teams, as well as individually (Ahmed et al., 2012) which calls for good interpersonal and communication skills. The IS 2010 model curriculum has recognized the need for these non-technical skills and has included them under the foundational knowledge areas with emphasis being on leadership and collaboration, communication, negotiation, analytical and critical thinking, which are grouped under the leadership and communication and individual and organizational knowledge work capabilities (Topi et al., 2010). Therefore, the IS curriculum should impact these non-technical skills to the IS graduates and thus contribute to the success of systems analyst when working with the different stake- 
holders. The ability to effectively work with teams and end-users were also found to be two types of critical non-technical skills needed of a systems analyst (Powell \& Yager, 2013).

Even though only a few job advertisements specified certification as a requirement, as shown in Table 7, only $50 \%$ of the IS professionals indicated that certification was important. Usually, a certification is an indicator that one has mastered the subject matter and can be used as a bargaining tool by the prospective job seekers when combined with a quality grade point average.

\section{Limitations and Future Studies}

The current empirical study is based on data that was gathered in the US. Future studies should explore other regions, more so on the emerging economies. Although the sample size for the IS professionals is plausible, future studies should aspire to expand the sample size as well as diversify the industry sectors from where the data is collected. There is a dearth of research studies investigating the type and level of degree as well as certification and years of experience for systems analysts and future studies should extrapolate on this line of research with more diverse data sets.

\section{Conclusion}

The basic skills required for systems analysts are usually gained at an accredited university, while only a small number of systems analyst professionals receive on-the-job training. While traditional classroom experiences are beneficial, exposure to emerging practices in the field will enhance the value of entry-level systems analysts. Also, universities try to make their programs as broad and appealing as possible but not all functions can be covered. A vast majority of universities allocate the majority of their students' credit hours to core courses, leaving little room for general business skills beyond prerequisites (Gorman, 2011). Thus, when educating future systems analysts, educators must take into account the different job markets and their needs, including the economic and social changes in the labor market (Thiele, 2014). By identifying what recruiters are looking for in a systems analyst, universities can better tailor their programs to the evolving job market while concurrently increasing placement for their graduates.

A successful systems analyst must be not only technically proficient, but also cooperative, detail oriented, and able to communicate with diverse groups. There is a constant struggle between the educational programs as they strive to align their programs/curriculums to the demands and the needs of the industry. Revisions are currently being suggested to the top IS programs that would require schools to reevaluate their program of study every five years (Gorman, 2011).

For universities, there are a number of initiatives that they can take to equip their students who wish to pursue a career as systems analysts with the requisite skills and knowledge. For instance, the schools can work with external clients in designing and implementing capstone projects that closely mimic the real world practical experiences expected in the job market. As earlier mentioned, internship also offers students' opportunities to experience the job market environments before they graduate and decide if that is their preferred career path. In acquiring the nontechnical skills e.g. communicating skills, presentations skills, and technical writings skills, students can be involved in Toastmasters activities or case competitions. 


\section{References}

Adams, S., (2013). The 10 best websites for your career-2013. Forbes. Retrieved October 11, 2015 from http://www.forbes.com/sites/susanadams/2013/09/18/the-10-best-websites-for-your-career-2013/

Ahmed, F., Capretz, L. F., \& Campbell, P. (2012). Evaluating the demand for soft skills in software development. IT Professional, 14(1), 44-49.

Banerjee, S., \& Lin, W. (2006). Essential entry-level skills for systems analysts. Journal of Education for Business, 81(5), 282-286.

Bureau of Labor Statistics, U.S. Department of Labor, Occupational Outlook Handbook. (2014-15 Edition). Computer Systems Analysts. Retrieved March 21, 2015 from http://www.bls.gov/ooh/computer-andinformation-technology/computer-systems-analysts.htm

Downey, J. P., McMurtrey, M. E., \& Zeltmann, S. M. (2008). Mapping the MIS curriculum based on critical skills of new graduates: An empirical examination of IT professionals. Journal of Information Systems Education, 19(3), 351-363.

Friedman, T. L. (2006). The world is flat [updated and expanded]: A brief history of the twenty-first century. Macmillan.

Gorgone, J., Davis, G. B., Valacich, J. S., Topi, H., Feinstein, D. L., \& Longenecker, H. E. (2003). IS 2002 model curriculum and guidelines for undergraduate degree programs in information systems. Соттиnications of the Association for Information Systems, 11(1), 1.

Gorman, M. F. (2011). A case study in effectively bridging the business skills gap for Information Technology professionals. Journal of Education for Business, 86(1), 17-24.

Green, G. I. (1989). Perceived importance of systems analysts' job skills, roles, and non-salary incentives. MIS Quarterly, 115-133.

Griffith, E. (2015). The best job search websites \& apps, PCMag, Retrieved October 11, 2015 from http://www.pcmag.com/slideshow/story/294523/the-best-job-search-websites-apps

Guidry, B. N., \& Stevens, D. P. (2014). Comparing perceptions of the systems analysis and design course. Journal of Computer Information Systems, 55(1), 40-47.

Guidry, B. N., Stevens, D. P., \& Totaro, M. W. (2011). The systems analysis and design course: An educators' assessment of the importance and coverage of topics. Journal of Information Systems Education, 22(4), 331.

Haga, W., Moreno, A., \& Segal, M. (2012). Is student performance on the information systems analyst certification exam affected by form of delivery of information systems coursework. Information System Education Journal, 10(5), 30.

Hirschheim, R., \& Klein, H. K. (2012). A glorious and not-so-short history of the information systems field. Journal of the Association for Information Systems, 13(4), 188.

Joseph, D., Ang, S., Chang, R., \& Slaughter, S. (2010). Practical intelligence in IT: Assessing soft skills of IT Professionals. Communications of the ACM, 53(2), 149-154.

Karanja, E., \& Zaveri, J. (2012). IT leaders: Who are they and where do they come from? Journal of Information Systems Education, 23(2), 143.

$\mathrm{Ku}, \mathrm{W}$. (2014). Careers in the 21st Century. Children's Technology \& Engineering, 18(4), 32-33.

Lee, C. K. (2005). Analysis of skill requirements for systems analysts in Fortune 500 organizations. Journal of Computer Information Systems, 45(4), 84-92.

Lee, K., \& Mirchandani, D. (2010). Dynamics of the importance of IS/IT skills. Journal of Computer Information Systems, 50(4), 67-78.

Lerouge, C., Newton, S., \& Blanton, J. E. (2005). Exploring the systems analyst skill set: Perceptions, preferences, age, and gender. Journal of Computer Information Systems, 45(3), 12-23. 
McMurtrey, M., Downey, J., Zeltmann, S., \& Friedman, W. (2008). Critical skill sets of entry-level IT professionals: An empirical examination of perceptions from field personnel, Journal of Information Technology Education, 7(1), 101-120. Retrieved from http://www.informingscience.org/Publications/181

Misic, M. M., \& Graf, D. K. (2004). Systems analyst activities and skills in the new millennium. Journal of Systems and Software, 71(1), 31-36.

Nastasi, B. (1998). Study notes: Qualitative research: Sampling \& sample size considerations. Adapted from a presentation by Dr. Bonnie Nastasi, Director of School of Psychology Program.

Noll, C., \& Wilkins, M. (2002). Critical skills of IS professionals: A model for curriculum development. Journal of Information Technology Education: Research, 1(3), 143-154. Retrieved from http://www.informingscience.org/Publications/352

Patton, M. Q. (1990). Qualitative evaluation and research methods (pp. 169-186). SAGE Publications.

Pierson, J. K., Kruck, S. E., \& Teer, F. (2008). Trends in names of undergraduate computer-related majors in AACSB-accredited schools of business in the USA. Journal of Computer Information Systems, 49(2), 26-31.

Powell, A., \& Yager, S. (2013). Research in progress / teaching systems analysis and design: What do students really need to know? In Proceedings of the 2013 Annual Conference on Computers and People Research (pp 99-104). ACM.

Satzinger, J., \& Jackson, R. (2012). Systems analysis and design in a changing world (6 ${ }^{\text {th }}$ ed.). Boston, MA: Course Technology, Cengage Learning.

Thiele, L. (2014). Careerlink skills: Analyzing IT skills from online job postings. AIM, 1(1), 2-13. Retrieved November 28, 2014 from http://cdn.aimforbrilliance.org/pdf/CareerlinkSkills2014.pdf-

Topi, H., Valacich, J. S., Wright, R. T., Kaiser, K., Nunamaker Jr, J. F., Sipior, J. C., \& de Vreede, G. J. (2010). IS 2010: Curriculum guidelines for undergraduate degree programs in information systems. Communications of the Association for Information Systems, 26(1), 18.

Yang, H., \& Cheng, H. (2009). Creative self-efficacy and its factors: An empirical study of information systems analysts and programmers. Computers in Human Behavior, 25(2), 429-438.

Wang, S., \& Wang, H. (2014). Redesigning the information systems analysis and design course: Curriculum renewal. Journal of Computer Information Systems, 55(1), 30-39.

Woratschek, C. R., \& Lenox, T. L. (2002, October). Information systems entry-level job skills: A survey of employers. In Proceedings of the Information Systems Educators Conference, San Antonio TX (Vol. 19). 


\section{Biographies}

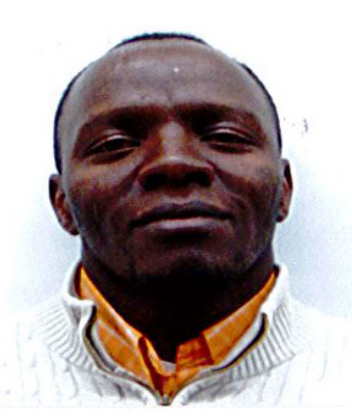

Erastus Karanja is an Assistant Professor in the Computer Information Systems (CIS) Department in the School of Business at North Carolina Central University. He holds a PhD in Business Administration and an MS in Computer Science. He is also a certified Project Management Professional (PMP). Dr. Karanja's research explores IT strategy, Innovation, and IT pedagogy. His research has been published in a number of research articles such as the International Journal of Information Management, International Journal of Accounting \& Information Management, Journal of Systems and Information Technology, Journal of Information Technology Management, Journal of Business and Management, Journal of Business Information Systems, Journal of Information Systems Education, and Journal of Negro Education, among others. He has also presented his research at various local and international conferences.

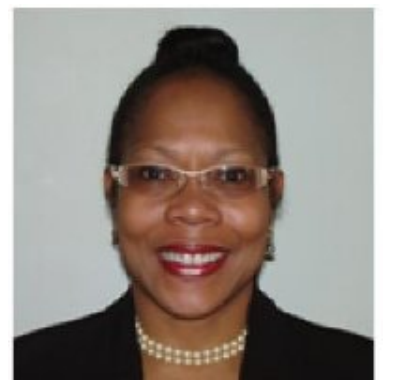

Donna M. Grant is an Associate Professor and the Chair of Computer Information Systems (CIS) Department in the School of Business at North Carolina Central University (NCCU). Dr. Grant is also the Program Coordinator for the Computer Science and Business interdisciplinary degree program. She received her Ph.D. from DePaul University (2007) where she also earned an M.S. in Information Systems with a concentration in Project Management (2002) and an M.B.A. in Finance (1981). Additionally, she earned a B.S. in Mathematics at Northwestern University. Dr. Grant has been teaching at NCCU for eight years and has received the NCCU award for Teaching Excellence. Furthermore, Dr. Grant has published her research in the Journal of Information Technology Education, the International Journal of Cloud Computing, the Encyclopedia of Gender and Information Technology, the Informing Science Journal and various Information Systems conferences. Dr. Grant has received the IBM Faculty award for six years (2009, 2010, 2011, 2013, 2014 and 2015).

Prior to completing her second Masters and beginning her doctoral program, Dr. Grant spent 22 years in the IT industry. Dr. Grant started her career as a programmer in 1977 at Illinois Bell, and was also a Business Analyst, Data Base Administrator and Manager until she became a Director at Ameritech in 1989 where she was responsible for the Billing Systems and supervised people in 5 states with a $\$ 238.8 \mathrm{M}$ expense budget and $\$ 60 \mathrm{M}$ capital budget.

Dr. Grant was born and raised in Chicago. She has two sons, Larry and Lance and three granddaughters, Camille, Camryn and Felicia. All of her children, grand-children and mother still reside in Chicago.

Shinetta Freeman works in the software development industry. She holds a Master's of Science degree in Management Information Systems with a concentration in Project Management from Bowie State University and a Bachelor's of Science degree in Business Management with a concentration in Finance from Bowie State University. 


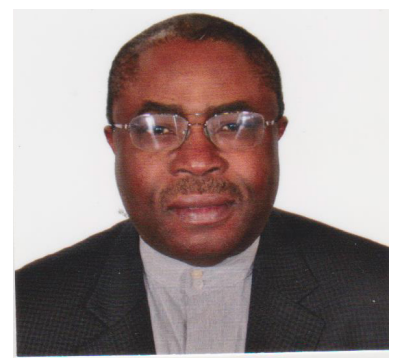

David Anyiwo is a Professor of Information Systems and the Chair of the Information Systems Department at Bowie State University. He has led innovative research efforts at several U.S. and international universities, public agencies and corporations. His work spans the fields of business intelligence and analytics, agent-based computing, semantic web security, agile software engineering, project/change management, smart grid operations technology integration, as well as advanced energy and resource systems engineering and management. He has authored book chapters and published several technical papers in leading professional journals and conference proceedings, and serves on the editorial boards of several publishing companies as well as on the program and advisory committees of numerous national and international conferences.

He holds a doctorate degree in Systems Engineering from the University of Virginia, as well as baccalaureate and master's degrees in Industrial Engineering and Operations Research from the University of Massachusetts. He also completed a comprehensive program of Advanced Study in Intelligent Decision Systems at the National Defense University, and has received numerous recognitions and awards. 